$2-2020$

\title{
Psychosocial implications in breast cancer
}

Daniyal Aamir

Yamna Waseem

Mustafa Saleem Patel

Follow this and additional works at: https://ecommons.aku.edu/pakistan_fhs_mc_mc

Part of the Oncology Commons, Psychiatry and Psychology Commons, and the Women's Health Commons 


\section{STUDENTS' CORNER LETTER TO THE EDITOR}

\section{Psychosocial implications in breast cancer}

Daniyal Aamir, ${ }^{1}$ Yamna Waseem, ${ }^{2}$ Mustafa Saleem Patel ${ }^{3}$

Madam, breast cancer is the most prevalent type of cancer amongst females, with an estimated 1 in 9 women in Pakistan falling prey to this disease at some point in their lives. ${ }^{1}$ Several women attribute the incidence to adverse life events and the rising levels of stress, which has been linked to a deterioration in neuroendocrine and immune systems. ${ }^{2}$ Recently, several researches have been undertaken to elucidate the correlation between stress and cancer.

The proposed mechanism of action behind the role of stress in the implication of cancer includes alterations in the hypothalamus-pituitary-adrenal axis regulating glucocorticoid and catecholamine levels, which has been linked with a compromise in DNA repair and an upregulation of tumour cell growth and angiogenesis. ${ }^{3}$ Moreover, norepinephrine, part of the body's fight-orflight response system, has been implicated in angiogenesis and metastasis. ${ }^{2}$ Several experiments have proved an association between breast cancer and chronic stress. In one experiment, tumours transplanted into the mammary fat pads of mice had a much higher rate of metastasis to the lungs in mice which were exposed to stressful conditions, as compared to mice which were not stressed. $^{3}$

Psychosocial oncology is an upcoming area of interest, which deals with numerous psychiatric, psychological, and social aspects of malignancies. The prevalence of psychological disorders in patients with cancer range from $29 \%$ to $47 \%, 4$ which can further hasten the development of breast cancer. Given that the prevalence of depression in Pakistan is $6 \%, 5$ and is continuing to rise, oncologists must maximize psychological care as an adjunct to oncological treatment in order to provide a cost-effective method for reducing prevalence.

14th Year MBBS Student, Aga Khan University, Karachi, 24th Year MBBS Student, 35th Year MBBS Student, Dow University of Health Sciences, Karachi, Pakistan.

Correspondence: Yamna Waseem. Email: yamna_wr@hotmail.com
Caregivers should be made aware of alleviating stressful situations and promoting an amiable standard of living for the patient, whilst promoting regular visits with trained professionals to ensure minimal stress to patients. Interventions should be tackled at improving, not only the physical well- being of the patient, but also their psycho-social state. ${ }^{6}$ It has been shown that women who are provided with counselling tend to develop fewer sideeffects and generally have a superior quality of life, as compared to those who are not offered counselling services. ${ }^{6}$ These should be delivered in a way which is both accessible and viable. A few methods that have been employed by previous studies include, but are not limited to, telephone conversations, emails, support groups, exercise therapy and cognitive behavioural therapy. Such methods should be employed on a larger level to improve healthcare provision to breast- cancer patients.

Disclaimer: None to declare.

Conflict of Interest: All authors affirm that they have nothing significant to reveal.

Funding Disclosure: None to declare.

\section{References}

1. Usman MS, Mustafa RM, Shaikh FH, Siddiqi TJ. Is a psychological approach required to combat breast cancer mortality in Pakistan? Arch Womens Ment Health. 2019; 22:541-2.

2. Chiriac VF, Baban A, Dumitrascu DL. Psychological stress and breast cancer incidence: a systematic review. Clujul Med. 2018; 91:18-26.

3. Schoemaker MJ, Jones ME, Wright LB, Griffin J, McFadden E, Ashworth A, et al. Psychological stress, adverse life events and breast cancer incidence: a cohort investigation in 106,000 women in the United Kingdom. Breast Cancer Res. 2016; 18:72.

4. İzci F, İlgün AS, Fındıklı E, Özmen V. Psychiatric Symptoms and Psychosocial Problems in Patients with Breast Cancer. J Breast Health. 2016; 12:94-101.

5. Khalily MT. Mental health problems in Pakistani society as a consequence of violence and trauma: a case for better integration of care. Int J Integr Care. 2011; 11:e128.

6. D'Egidio V, Sestili C, Mancino M, Sciarra I, Cocchiara R, Backhaus I, et al. Counseling interventions delivered in women with breast cancer to improve health-related quality of life: a systematic review. Qual Life Res. 2017; 26:2573-92.

https://doi.org/10.5455/JPMA.48474 